Environment Conservation Journal 14(3) 69-72, 2013

ISSN 0972-3099 (Print) 2278-5124 (Online)

Abstracted and Indexed

\title{
Over dosing trend of insecticides for sucking pest management in cotton in west Madhya Pradesh
}

\author{
S. B. Singh ${ }^{1}$, R. K. Choudhary ${ }^{1}$ and A. Siddiqui ${ }^{2} \bowtie$ \\ Received: 02.08.2013 \\ Revised: 03.10.2013
}

Accepted: 23.10.2013

\begin{abstract}
The study was undertaken during 2011 and 2012 in five tehsils of Nimar region (West Madhya Pradesh) around the Narmada river, namely-Sanawad, Badwani, Khargone, Maheshwar and Dhamnod to know the over dosing trend and adverse effect of insecticides against sucking insect pest of cotton. In each location ten farms of different categories were selected based on acre age as F-1(up to 02 acres), F-2 (up to 04 acres), F-3 (up to 06 acres), F-4 (up to 08 acres), F-5 (up to 10 acres), F-6 (up to 12 acres), F-7 (up to 14 acres), F-8 (up to 16 acres), F-9 (up to 18 acres) and F-10 (More than 18 acres). All the information about insecticidal applications was received through discussion with farmers. The received information by each farmer of same category of ten locations about applied dose of insecticides and per cent reduction in insect population in each spray was averaged. The averaged data about insecticidal dose was converted into per cent increase over recommended dose of each insecticide and tabulated. The higher dose of acetamiprid 20 SP imidacloprid 17.8 SL, thiamethoxam 25WG, monocrotophos 36 SL, thiacloprid 21.7 SC and diafenthiuron 50WP was 36.01,45.89\%, $64.61 \%, 72.10 \%, 79.24 \%$ and $85.60 \%$ in first, second, third, fourth, fifth and last spray, respectively. The reduction in insect pests population was found 55.40-72.40\%, 52.50-60.50\%, 51.25-58.25\% 57.20-66.65\% 50.75-63.25\% and 55.40$\mathbf{6 8 . 2 5} \% \%$ in first, second, third, fourth, fifth and last spray, respectively and overall averaged as 57.76-62.22\%. From all the observations it was concluded that the application of higher dose of any insecticide did not reduce the sucking pest population much more than the recommended dose.
\end{abstract}

Keyword: Nimar region, cotton, sucking pests, recommended dose, overdosing

\section{Introduction}

Indian farmers are still not well known about the technical information and justified use of insecticides therefore they are using it indiscriminately in various crops against insect pests. Cotton is the main kharif crop of Nimar region and this crop suffers greatly due to infestation of various insect pests. After the introduction of $B t$ cotton the intensity of sucking pests increased and crop suffers greatly from the initial stage of crop till the maturity. Previously in non $B t$ cotton, farmers were using on an average six sprays of different insecticides to control the insect pests of different groups with normal or recommended doses. Since last few years, the mono cropping of $B t$ cotton, increased the load of sucking pests and also the resistance against insecticides The wide use of synthetic organic insecticides, synthetic pyrethroids and in recent years other new Author's Address

${ }^{1}$ College of Agriculture, Residency Area, Indore (M.P.)

${ }^{2}$ Govt. Holkar Sc. College, Indore (M.P.)

Email: anissiddiqui1956@gmail.com groups of insecticides like neonicotinoids, pyrroles, phenylpyrazole and macrocyclic lactones against insect pests, has lead to multifold resistance to insecticides. The attraction of cotton growers towards the crop, has compelled to apply the higher doses of insecticides which causes hazardous effect on crop, soil and water due to their residues, as the fact is well established. In the present investigation efforts has been made to estimate the over dosing of insecticides by the farmers and per cent reduction of sucking pests population in different locations of Nimar region.

\section{Material and methods}

Study Area: Five tehsils of Nimar region around the Narmada river, namely-Sanawad, Badwani, Khargone, Maheshwar and Dhamnod, were selected for study as the farmers of these tehsils generally grow $B t$ cotton as major crop in kharif season. In each tehsil two big villages of opposite locations were also selected and farmers were categorized and listed for the study. 


\section{Methodology}

The study was undertaken in ten different locations of Nimar region during kharif season of 2011 and 2012 to know about the over dosing of insecticides in all the sprays done in cotton to protect the crop from sucking pest. The experiment was planned after a number of surveys in different locations of Nimar region related with number of spraying, name of insecticides applied, application of higher doses of insecticides in each spray and per cent reduction of sucking pests. In each location ten farmers of different categories were selected based on their land holdings and described as category1(up to 02 acres),category-2 (up to 04 acres), category-3 (up to 06 acres), category-4 (up to 08 acres), category-5 (up to 10 acres), category-6 (up to 12 acres), category-7 (up to 14 acres), category- 8 (up to 16 acres), category-9 (up to 18 acres) and category-10 (more than 18 acres). Each farmer of different category was interviewed through discussion about crop protection. The received information in each spray by each farmer of same category of ten locations was averaged and considered as F1, F2, F3, F4, F5, F6, F7, F8, F9 and F10. Data received for two years, was averaged and converted into per cent increase dose over recommended dose of each insecticide and tabulated. An overall mean was also calculated for the data of all the categories of each spray for accurate representation.Similarly per cent reduction of sucking insect pest complex namely-leafhopper, Amrasca biguttula biguttula (Ishida), aphid, Aphis gossypii Glover, whitefly, Bemisia tabaci (Gennadius) and thrips, Thrips tabaci Lindeman, was also received and averaged and compared with sucking pests population reduction at recommended dose. The separate study was undertaken at college of agriculture, Indore to know the per cent reduction of sucking insect pest complex during both the years and averaged. Spray schedule of insecticides is detailed below in which sprays were made at 10 days interval. All the facilities were provided by the field staff of Bayer crop science India.

\section{Results and Discussion}

It was noticed (Table 1) that farmers of all groups applied increased insecticidal dose than recommended dose from first spray to the last spray. All the group of farmers sprayed insecticides indiscriminately and non judiciously in all the six sprays. The average higher dose of acetamiprid 20 SP (36.01\%) was applied in first spray followed by imidacloprid 17.8 SL (45.89\%) in second spray, thiamethoxam 25WG (64.61\%) in third spray, monocrotophos $36 \mathrm{SL}$ (72.10\%) in fourth spray, thiacloprid 21.7 SC (79.24\%) in fifth spray and diafenthiuron 50 WP $(85.60 \%)$ in last spray. The highest increase in insecticidal dose over previous spray was observed in third spray $(18.72 \%)$ and it was lowest in last spray $(6.36 \%)$ and averaged as $9.91 \%$ in all the sprays. Such increase in each insecticidal spray might be due to suggestions of dealers and farmers doing experiment every day based on the need to control the insect pest population up to maximum limit, lack of knowledge about insecticides and increasing insecticidal resistance to insects. The average reduction in insect pest population (Table 2) was found $55.40-72.40 \%$ (first spray), $52.50-60.50 \%$ (second spray), 51.25-58.25\% (third spray), 57.20$66.65 \%$ (fourth spray), $50.75-63.25 \%$ (fifth spray) and $55.40-68.25 \%$ (sixth spray) and overall averaged as 57.76-62.22\%. From all the observations it was revealed that there was less than five per cent increase in insect pests mortality due to over dosing of insecticides than recommended dose.From all the observations it was concluded that the application of higher dose of any insecticide did not reduce the sucking pest population much more than the recommended dose. It is well established that over dosing of insecticides increase insect resistance, resurgence, mortality of natural enemies like predators and parasitoids, creates phytotoxicity, soil and water pollution ,human hazards and monetary loss of farmers. The present investigation is in partial conformity with the findings of. Agarwal et al. (2010) who reported that even at low concentration, pesticides may exert several adverse effects which could be monitored at biochemical, molecular or behavioral levels. The factors affecting water pollution with pesticides and their residues include drainage, rainfall, microbial activity, soil temperature, treatment surface, application rate as well as the solubility, mobility and half life of pesticides. 
Over dosing trend of insecticides for sucking pest

Table 1: Over dosing of insecticides against sucking insect pests of cotton in Nimar region of Madhya Pradesh

\begin{tabular}{|c|c|c|c|c|c|c|c|c|c|c|c|c|c|c|c|c|c|c|}
\hline \multirow{3}{*}{ 窇 } & \multicolumn{18}{|c|}{ Per cent increase in insecticidal dose } \\
\hline & \multicolumn{3}{|c|}{$\begin{array}{c}\text { Ist spray } \\
\text { Actamiprid } 20 \mathrm{SP}\end{array}$} & \multicolumn{3}{|c|}{$\begin{array}{c}\text { IInd spray } \\
\text { Imidacloprid17.8SL }\end{array}$} & \multicolumn{3}{|c|}{$\begin{array}{c}\text { IIIrd spray } \\
\text { Thiamethoxam } 25 \mathrm{~W} \\
\text { G }\end{array}$} & \multicolumn{3}{|c|}{$\begin{array}{c}\text { IVth spray } \\
\text { Monocrotophos } 36 \\
\text { SL }\end{array}$} & \multicolumn{3}{|c|}{$\begin{array}{c}\text { Vth spray } \\
\text { Thiacloprid 21.7 SC }\end{array}$} & \multicolumn{3}{|c|}{$\begin{array}{c}\text { VIth spray } \\
\text { Diafenthiuron }\end{array}$} \\
\hline & 2011 & 2012 & Mean & 2011 & 2012 & Mean & 2011 & 2012 & Mean & 2011 & 2012 & Mean & 2011 & 2012 & $\begin{array}{l}\text { Mea } \\
\text { n }\end{array}$ & 2011 & 2012 & Mean \\
\hline F1* & 32.5 & 35.2 & 33.85 & 46.3 & 43.3 & 44.80 & 64.2 & 61.5 & 62.87 & 68.2 & 75.2 & 77.74 & 65.2 & 78.2 & 71.2 & 86.6 & 93.5 & 90.05 \\
\hline F2 & 34.2 & 33.5 & 33.87 & 42.5 & 45.2 & 43.85 & 63.3 & 66.2 & 64.8 & 75.5 & 62.1 & 68.82 & 72.5 & 75.5 & 74.0 & 88.2 & 86.2 & 87.22 \\
\hline F3 & 33.3 & 31.7 & 32.52 & 44.4 & 46.4 & 45.45 & 67.2 & 61.5 & 69.37 & 73.2 & 78.2 & 75.73 & 78.2 & 80.5 & 79.3 & 83.5 & 88.7 & 86.10 \\
\hline F4 & 38.2 & 37.5 & 37.87 & 43.3 & 44.5 & 43.92 & 61.5 & 69.2 & 65.37 & 78.5 & 79.5 & 79.00 & 82.3 & 88.4 & 85.3 & 85.2 & 79.5 & 82.37 \\
\hline F5 & 36.2 & 34.2 & 35.25 & 48.2 & 41.5 & 44.85 & 65.6 & 62.3 & 63.98 & 72.2 & 68.2 & 70.24 & 79.5 & 83.2 & 81.3 & 78.5 & 81.5 & 80.02 \\
\hline F6 & 40.5 & 36.9 & 38.70 & 45.5 & 46.7 & 46.12 & 62.4 & 67.5 & 64.95 & 68.5 & 71.2 & 69.87 & 80.2 & 76.4 & 78.3 & 76.7 & 94.5 & 85.66 \\
\hline F7 & 31.2 & 38.5 & 37.87 & 46.2 & 45.5 & 45.87 & 68.6 & 61.5 & 65.08 & 66.2 & 74.2 & 70.26 & 78.5 & 81.5 & 80.0 & 79.5 & 93.2 & 86.39 \\
\hline F8 & 36.3 & 40.2 & 38.30 & 48.7 & 48.2 & 48.45 & 60.2 & 66.3 & 63.27 & 79.4 & 72.5 & 75.97 & 83.4 & 74.2 & 78.8 & 83.5 & 87.5 & 85.50 \\
\hline F9 & 37.4 & 37.7 & 37.57 & 46.2 & 50.5 & 48.37 & 63.5 & 69.5 & 66.52 & 62.4 & 70.2 & 66.35 & 81.2 & 79.6 & 80.4 & 86.5 & 85.5 & 86.02 \\
\hline F10 & 35.3 & 39.3 & 37.32 & 48.2 & 46.2 & 47.22 & 62.5 & 67.5 & 65.02 & 74.4 & 71.6 & 73.02 & 87.2 & 78.5 & 82.8 & 87.2 & 86.2 & 86.76 \\
\hline $\begin{array}{l}\text { Mea } \\
\text { n }\end{array}$ & 35.5 & 36.4 & 36.01 & 45.9 & 45.8 & 45.89 & 63.9 & 65.3 & 64.61 & 71.8 & 72.3 & 72.10 & 78.8 & 79.6 & 79.2 & 83.5 & 87.6 & 85.60 \\
\hline
\end{tabular}

*F1- Group of 10 farmers of same category in different location.

Table 2: Average reduction in sucking insect pests population during 2011 and 2012 after over dosing in each spray.

\begin{tabular}{|c|c|c|c|c|c|c|c|}
\hline \multirow[t]{2}{*}{ Farmers } & \multicolumn{7}{|c|}{ *Mean population reduction per cent $(2011$ \& 2012$)$} \\
\hline & \begin{tabular}{l}
\multicolumn{1}{c}{ Ist spray } \\
Actamiprid \\
$20 \mathrm{SP}$
\end{tabular} & $\begin{array}{l}\text { Ind spray } \\
\text { Imidaclopri } \\
\text { d17.8SL }\end{array}$ & \begin{tabular}{l}
\multicolumn{1}{c}{ IIIrd spray } \\
Thiamethoxam \\
25WG
\end{tabular} & $\begin{array}{l}\text { IVth spray } \\
\text { Monocrotophos } \\
\text { 36 SL }\end{array}$ & $\begin{array}{l}\text { Vth spray } \\
\text { Thiacloprid } \\
21.7 \mathrm{SC}\end{array}$ & $\begin{array}{c}\text { VIth spray } \\
\text { Diafenthiuron }\end{array}$ & $\begin{array}{l}\text { Overall } \\
\text { Mean }\end{array}$ \\
\hline F1 & 65.50 & 60.50 & 55.50 & 62.50 & $51 . .25$ & 68.25 & 60.58 \\
\hline F2 & 58.50 & 54.25 & 58.25 & 64.25 & 56.50 & 62.55 & 59.05 \\
\hline F3 & 70.60 & 57.25 & 52.50 & 58.75 & 55.60 & 59.50 & 59.03 \\
\hline F4 & 72.40 & 63.40 & 56.25 & 65.50 & 58.25 & 57.54 & 62.22 \\
\hline F5 & $\mathbf{5 5 . 4 0}$ & 58.50 & 53.75 & 58.20 & 61.40 & 65.50 & 58.79 \\
\hline F6 & 64.85 & 55.50 & 56.75 & 62.80 & 53.70 & 57.40 & 58.50 \\
\hline F7 & 66.50 & 62.40 & 54.50 & 66.65 & 61.25 & 55.40 & 61.16 \\
\hline F8 & 58.65 & 66.25 & 51.25 & 57.20 & 56.50 & 62.80 & 58.77 \\
\hline F9 & 64.40 & $\mathbf{5 2 . 5 0}$ & 57.40 & 63.75 & 50.75 & 57.80 & 57.76 \\
\hline F10 & 69.40 & 56.45 & 56.50 & 64.50 & 63.25 & 60.25 & 61.72 \\
\hline Mean & 64.62 & 58.70 & 55.26 & 62.41 & 56.84 & 60.69 & 59.75 \\
\hline $\begin{array}{l}\text { Mean population } \\
\text { reduction per cent } \\
\text { at recommended } \\
\text { dose }\end{array}$ & 62.50 & 55.25 & 53.40 & $\mathbf{5 9 . 5 0}$ & 53.25 & $\mathbf{5 8 . 6 0}$ & 56.80 \\
\hline
\end{tabular}

*Mean population reduction observed at $10 \mathrm{DAS}$

71

Environment Conservation Journal 
Singh et al. (2008) indicated hazardous effect of insecticides in blood level in vertebrates causes reproductive dysfunction and suggested that for human beings food like fish, chick and goat containing beyond permissible limit of insecticides must be avoided. In relation to hazardous effect of insecticides present study is in close association with this finding. The results of present study are in the line of findings reported by Yadav et al. (2009) who felt the need for the motivation of farmers towards reduced consumption of pesticides, adoption of approaches to overcome the problem of insecticide resistance, conservation of natural enemies and awareness regarding right chemical, dose, time and method of pesticide application to reduce the cost of cultivation. The findings of Dhillon et al. (2012) are in close conformity with present investigation who observed that insecticide application resulted in resurgence of cotton aphid and whitefly, possibly because of elimination of natural enemies or better growth of plants under protected conditions. Abundance of bollworms, non-target pests, and generalist predators was significantly greater before insecticide sprays than after insecticide application, except in a few cases. The findings of Kumar et al (2010) are in contradiction with the present study as they reported cotton plants sprayed with flubendiamide + thiacloprid $480 \mathrm{SC}$ each at 120 , 240 and $480 \mathrm{~g}$ a.i.ha ${ }^{-1}$ doses did not show any phytotoxic symptoms like epinasty, hyponasty, leaf injury, wilting, vein clearing and necrosis. Similarly Yadav et al (2004) revealed that the ready-mix insecticides had no phytotoxic effect on okra when applied at normal, double and four times the recommended doses. These contradictions might be due to changes in climatic conditions like continuous and heavy rainfall just after insecticide application and method of application.

\section{Acknowledgement}

The authors are highly thankful to the Bayer Crop Science, India for providing necessary facilities to undertake the present investigation in the field with help of their field staff.

\section{References}

Agrawal, Anju., Pandey, R.S. and Sharma, Bechan.2010. Water pollution with special reference to pesticide contamination in India. Journal of Water Resource and Protection. 2(5):432-448.

Dhillon, M. K., Pampapathy, G., Wadaskar, R. M. and Sharma, H. C. 2012. Impact of Bt transgenic cottons and insecticides on target and non-target insect pests, natural enemies and seed cotton yield in India. Indian Journal of Agricultural Sciences. 82(3):248-254.

Kumar, B. V., Boomathi, N., Kumaran, N. and Kuttalam, S.2010. Combination of flubendiamide+thiacloprid 480 SC (RM) against bollworms and sucking pests of cotton.Madras Agricultural Journal. 97(4/6):157-160.

Singh, P.B., Singh, Vandana and Nayak, P.K.2008. Pesticide residues and reproductive disfunction in different vertebrates from north India. Food and Chemical Toxicology. 46(7):2533-2539.

Yadav, A. S., Choudhary, R. K., Sharma, R. C. and Parsai, S. K. 2009. Introduction of insecticide resistance management approach in south-west Madhya Pradesh: an interactive component of sustainable cotton cultivation technology.Trends in Biosciences. 2(1):13-15.

Yadav, Paras Nath., Chauhan, P.R. and R. Rana, M.K.2004. Phytotoxic effect of readymix insecticides on morphological characters of okra.Haryana Journal of Horticultural Sciences.33(1/2):150-151. 